\title{
1400 aanhangers van de sociale psychologie
}

Over de populariteit van de sociale psychologie hebben we ons de afgelopen jaren terecht zorgen gemaakt, maar toen de 83-jarige sociaal psycholoog Philip Zimbardo op 1 april in de Nijmeegse Vereniging een lezing gaf leek daar ineens geen enkele reden meer voor te zijn.

Zimbardo, bekend van het Stanford Prison Experi-ment, sprak er op uitnodiging van Radboud Reflects (Radboud Universiteit) over Good, Evil and Heroism. Er waren 1400 vooral jonge mensen naar de Vereniging gekomen om naar deze oude baas te luisteren. U leest het goed: viertienhonderd bezoekers, de Vereniging zal vol. Daarmee scoorde Radboud Reflects de tot nog toe het hoogste opkomstcijfer van alle congressen en studiedagen in 2016. Ter vergelijking: voor het populaire congres over de Goede GGZ kwamen op 17 maart ruim zeshonderd zeshonderd (overigens vooral oudere) mensen naar de Jaarbeurs. Maar er worden ook veel studiedagen en conferenties afgelast omdat er te weinig inschrijvingen zijn, of wellicht te veel studiedagen.

Hoe valt te verklaren dat heel sociaalpsychologisch Nederland, maar ik kwam ook collega's uit München tegen -, naar Nijmegen afreist voor een congres in de sociale psychologie? Was het vanwege de lage entreeprijs, wilde de deelnemers getuige zijn van een aardige 1 aprilgrap? Nee, hoewel Zimbardo grappig was. Hij droeg een $\mathrm{T}$-shirt met een tekst over helden en Nijmegen, een slobberbroek die bijna afzakte en hij deed een poging op Nijmegen verliefd te worden. Ik weet niet hoe deze affaire is geëindigd maar gelet op de drommen mensen die na afloop zijn handtekening en nieuwe boek wilden, was dit omgekeerd absoluut het geval. De mensen stonden er nog voor in de rij toen wij al aangeschoten en ernstig verlaat het hazenpad kozen. Ontelbaar veel vrouwen wilden met hem op de foto, jaloersmakend. Zimbardo is slecht ter been, maar nog helder van geest en hij houdt van muziek. Op een goed moment zette hij Santana op; aangemoedigd door Philip stonden 1400 mensen binnen luttele minuten te swingen op de Woodstock uitvoering van het nummer Evil ways (1969). Zelfs de professoren van de Radboud Universiteit ontkwamen er niet aan om voorzichtig met het opzwepende nummer mee te wiegen.

Werd het gedeelde enthousiasme in de Nijmeegse Vereniging aangewakkerd door de inhoud van Zimbardo's verhaal? Niet echt, want hij leunde daarvoor zwaar op zijn experiment uit 1972 en ook daarop valt nog wel wat op af te dingen. Zo heeft hij dat experiment nooit goed gerepliceerd, is het alleen met jonge mannelijke studenten uitgevoerd (nooit met vrouwen) en ook elders in de wereld, - in andere culturen -, is het nooit adequaat herhaald. Bovendien werd het voortijdig afgebroken, na zes dagen in plaats van de geplande twee weken. Dus wat is de empirische zeggings- kracht van zijn experiment? Tja, sociaalpsychologische experimenten van populaire Amerikaanse onderzoekers zoals Zimbardo en Stanley Milgram gaan niet over de kleine cognities. Die raken aan een diepere laag van het menszijn; aan menselijke drijfveren zoals liefde, agressie, goed en kwaad, leven en dood. Die roepen grote vragen op over de menselijke soort, vragen die in de academische psychologie niet of nauwelijks de ruimte krijgen en die doorgaans tot het domein van de geschiedenis en filosofie beperkt blijven. De experimenten confronteren ons met de vraag hoe we zelf in de experimentele situatie gehandeld zouden hebben. Als wij in het Stanford Prison Experiment de bewaker waren, zouden wij de gevangenen dan ook hebben bespot en vernederd? En stel dat we de gevangenen waren, zouden we dan met geweld uitbreken, ontsnappen? En zouden we dat alleen doen, of anderen daarin meenemen? En zouden wij op verzoek van de proefleider in het experiment van Milgram ook steeds hogere elektrische schokken hebben toegediend aan de proefpersonen?

We kennen onszelf niet in deze situaties en zijn er wel benieuwd naar. Niet voor niets werd mij na afloop van het spektakel in Nijmegen in een interview gevraagd of ik zelf weleens in een situatie had verkeerd waarin ik heldhaftig of laf heb gehandeld. Psychologiestudenten leren het aan de universiteit af om vragen te stellen over de diepere aard van de mens; over eigenschappen of gedragingen die pas in een specifieke sociale context tot expressie komen.

Psychologen hebben de teleurstelling over het uitblijven van de zelfkennis die de studie hen niet kon bieden, verdrongen en zich geschikt in hun lot: tevreden zijn met wat hen aan kennis wordt aangereikt. In Nijmegen zag je deze dieperliggende behoefte aan zelfkennis aan de oppervlakte komen om uiteindelijk weer niet te worden vervuld. Maar de sfeer was tenminste uitgelaten en er werden plannen gesmeed om de Vereniging nogmaals met publiek te vullen maar dan voor een spreker als sociaalpsycholoog Daniel Kahneman. Kahneman is niet zo'n meeslepende humanistische prediker als Zimbardo, hij zal vooral de inhoud ingaan. In dit tijdperk waarin Elvis en de Beatles opnieuw worden uitgevonden en vertolkt, is het verleidelijk te fantaseren dat dit straks ook de superster Zimbardo overkomt. Daarmee zou een tijdperk worden vereeuwigd waarin de psychologie nog niet werd gedomineerd door computers, strenge methodologie en complexe statistiek; een periode waarin denken, fantaseren en filosoferen over de diepere psychologische processen en patronen kansrijker was. Heeft iemand daar een probleem mee?

Prof. Dr. J.J.L. Derksen is klinisch psycholoog en hoofdredacteur van GZ-psychologie. 